Case Report

\title{
Nephrotic Syndrome Associated with Lung Cancer: A Rare Case of Malignancy Associated with AA Amyloidosis
}

\author{
Victor Gueutin, ${ }^{1}$ Anne-Lyse Langlois, ${ }^{1}$ Nathalie Shehwaro, ${ }^{1}$ Ryme Elharraqui, ${ }^{1}$ \\ Philippe Rouvier, ${ }^{2}$ and Hassane Izzedine ${ }^{1}$ \\ ${ }^{1}$ Department of Nephrology, Pitié-Salpêtrière Hospital, Assistance Publique-Hôpitaux de Paris, \\ Université Paris VI Pierre et Marie Curie, 47-83 Boulevard de l'Hôpital, 75013 Paris, France \\ ${ }^{2}$ Department of Pathology, Pitié-Salpêtrière Hospital, Assistance Publique-Hôpitaux de Paris, \\ Université Paris VI Pierre et Marie Curie, 47-83 Boulevard de l'Hôpital, 75013 Paris, France \\ Correspondence should be addressed to Hassane Izzedine; hassan.izzedine@psl.aphp.fr
}

Received 4 February 2013; Accepted 28 February 2013

Academic Editors: Y.-L. Chiu, H. Imai, Z. Korzets, and T. I. Steinman

Copyright (C) 2013 Victor Gueutin et al. This is an open access article distributed under the Creative Commons Attribution License, which permits unrestricted use, distribution, and reproduction in any medium, provided the original work is properly cited.

Nonhematologic malignancies are rarely reported to be associated with AA amyloidosis. Although the association between renal cell carcinoma and systemic AA amyloidosis has been established, the evidence linking pulmonary cancer to AA amyloidosis is scarce. Here, a case of biopsy-proven renal AA amyloidosis complicated with nephrotic syndrome associated with lung carcinoma is reported.

\section{Introduction}

Secondary (AA) amyloidosis is a disorder characterised by the extracellular tissue deposition of fibrils that are composed of fragments of serum amyloid A (SAA) protein [1]. Chronic inflammatory disease is a major cause of AA amyloidosis and nonhematologic malignancies are rarely reported to be associated with AA amyloidosis [2]. Excluding the tumors associated with localized amyloid, the incidence of generalized amyloidosis in patients with cancer has been estimated to be between 0.1 and $0.4 \%$ among all cancers [3]. From all cancers, renal carcinoma appears to be an important exception, because these tumors are responsible for 25$33 \%$ of all cancers associated with amyloidosis [4]. This low incidence of malignancy-related systemic AA amyloidosis seems to be linked to the short-term survival of cancer patients who died before significant systemic deposition of amyloid fibrils can occur. Although the association between renal cell carcinoma and systemic AA amyloidosis has been established, the evidence linking pulmonary cancer to AA amyloidosis is scarce $[2,5-7]$ and few reports concern mainly non small cell lung cancer and AA amyloidosis manifested by nephrotic syndrome $[2,5-8]$. We report here the case of nephrotic syndrome and renal failure due to systemic AA amyloidosis in a patient with nonsmall cell lung carcinoma (NSCLC).

\section{Case Report}

A 56-year-old man was referred to our hospital because of generalized edema, renal failure, and proteinuria. Chemounresponsive advanced NSCLC (stage IIIB adenocarcinoma) had been diagnosed on the left upper lung one year earlier. Medical history was unremarkable for recurrent infectious or chronic inflammatory disease, familial hypotension or neuropathy, and familial Mediterranean fever. Biochemical screening of renal function had been normal two months previously (baseline serum creatinine level of $0.76 \mathrm{mg} / \mathrm{dL}$ ).

Physical examination findings revealed generalized edema without breathing sound on the upper zone of the left lung. His blood pressure was $80 / 60 \mathrm{mmHg}$. Urinalysis revealed $3+$ proteinuria. Laboratory data were as follows: white blood cell count was $28,100 / \mathrm{mm}^{3}$, red blood cell count was $250 \times 10^{4} / \mu \mathrm{L}$, hemoglobin was $10.8 \mathrm{~g} / \mathrm{dL}$, hematocrit 


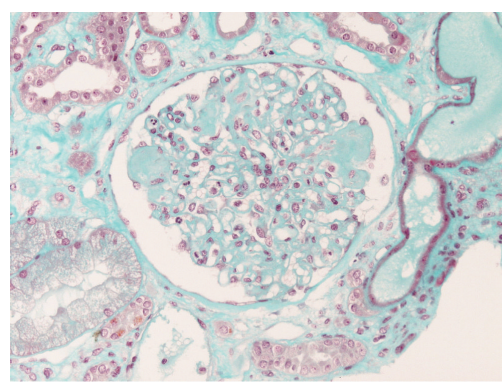

(a)

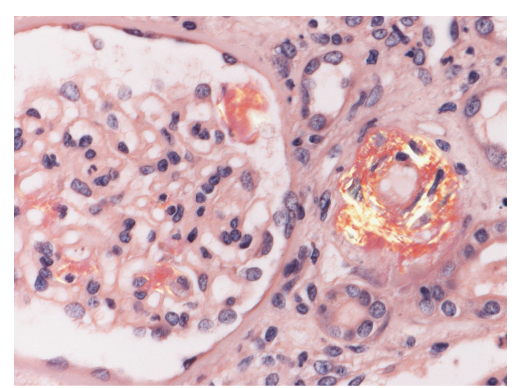

(b)

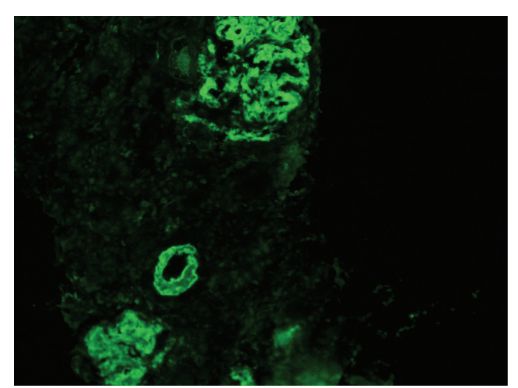

(c)

FIGURE 1: Histopathological findings of kidneys. (a) nodular appearance due to amorphous acellular mesangial deposition (Masson trichrome stain; magnification, $\times 200$ ). (b) accumulation of amyloid expanding the mesangial area and the arteriole (Congo red stain viewed by polarized light microscopy), (c) immunohistochemically positivity of AA amyloid (avidin-biotin-peroxidase complex system; original magnification, $\times 200)$.

was $36.1 \%$, platelet count was $20.8 \times 10^{4} / \mathrm{mm}^{3}$, total serum protein was $6.4 \mathrm{~g} / \mathrm{dL}$, albumin was $1.25 \mathrm{~g} / \mathrm{dL}$, creatinine was $3.09 \mathrm{mg} / \mathrm{dL}$, sodium was $137 \mathrm{mEq} / \mathrm{L}$, potassium was $4.0 \mathrm{mEq} / \mathrm{L}$, and chloride was $102 \mathrm{mEq} / \mathrm{L}$. The erythrocyte sedimentation rate (ESR) $(120 \mathrm{~mm} / \mathrm{h})$ and C-reactive protein (CRP) $(6.93 \mathrm{mg} / \mathrm{dL})$ were elevated, but no infections were found. The urine was $4+$ for protein and 10-15 red blood cells were observed per high power field. Twenty-four-hour urinary protein excretion was $12 \mathrm{~g}$; Bence-Jones proteinuria was not present. Serum protein and immunoelectrophoresis revealed hypoalbuminaemia with no monoclonal gammopathy rheumatoid factor, hepatitis B and C antigens, HIV serology, anti-GBM antibodies, myeloperoxidase and proteinase 3-antineutrophil cytoplasmic antibodies, and antinuclear antibody were all negative as well as tuberculin skin test. Ultrasound cardiography demonstrated good wall movement with a $58 \%$ ejection fraction, normal diastolic function, and mild aortic and pulmonary regurgitation and without granular pattern due to amyloid deposition.

Transjugular kidney biopsy was performed and histological examination showed homogenous massive amyloid deposits in glomeruli (Figure 1(a)) and vessel walls. This material produced apple-green birefringence under polarized light, (Figure 1(b)), by Congo red staining. The amyloid stained strongly with anti-AA (Figure $1(\mathrm{c})$ ) but not with anti- $\kappa$ or anti- $\lambda$ antiserum. Renal function deteriorated rapidly and the patient underwent palliative treatment.

\section{Discussion}

In our case, the absence of classic causes of chronic inflammation or infection suggests that AA amyloidosis was induced by the lung carcinoma.

In clinical series, the prevalence of renal involvement in patients with cancer is rather oriented glomerulopathies other than amyloidosis (e.g., membranous nephropathy, IgA nephropathy, minimal change nephropathy, rapidly progressive GN, membranoproliferative GN, crescentic glomerulonephritis, etc.). Lee et al. found that $11 \%$ of patients with the nephrotic syndrome had carcinoma [9].
Lung cancer is the leading cause of cancer deaths worldwide. The Tromso study describing an association between albuminuria and cancer showed a 5.4-fold increase risk for lung cancers in patients with an albumin-to-creatinine ratio in the highest quintile [10]. Lung cancer is among the malignancies commonly associated with a paraneoplastic nephrotic syndrome mostly related to membranous nephropathy [11]. The incidence of secondary AA amyloidosis during lung cancer is unknown. In a necropsy series, amyloid occurred in 6-10\% of bronchogenic carcinomas [12]; unfortunately, histological type was not mentioned. In 310 cases of squamous cell carcinoma with distal obstructive pneumonitis, no evidence of amyloidosis in the adjacent lung was found [6]. Furthermore, from 24,388 consecutive autopsies revealing 148 cases of amyloidosis, no cases of lung cancer were noted [13]. Indeed, only few cases of lung cancer presenting as renal AA amyloidosis have been reported (Table 1) [2, 5-9].

Renal AA amyloidosis seems to occur in the early years of evolution of lung cancer disease, mostly in nonsquamous cell lung cancer type. Recent data suggests that $20 \%$ of patients with metastatic renal cell carcinoma and high serum albumin A (SAA) levels survive for 5 years or more before developing systemic AA amyloidosis [14]. Renal abnormalities included nephrotic syndrome and acute or chronic renal failure that underwent dialysis.

In cancer patients, AA amyloidosis may be caused by the overproduction of SAA. We are not aware of the SAA level of our patient, but his CRP concentration had been elevated for at least 1 year prior to the current medical problem. Serum C-reactive protein and SAA correlate highly [15], and given the association between malignancies and serum amyloid A concentrations, a plausible hypothesis for the origin of our patient's AA amyloidosis would be a high SAA titre produced by the NSCLC. In the case of pulmonary metastasis of renal cancer [2] histopathological studies revealed that the tumor cells were surrounded by numerous lymphocytes, macrophages, and plasma cells, and AA amyloid was deposited in the outer layer of tumor cells and reactive cells, which suggests that the malignant cells were being encapsulated by immune cells. Indeed, proinflammatory 
TABLE 1: Biopsy-proven renal AA Amyloidosis associated with lung cancer.

\begin{tabular}{|c|c|c|c|c|c|c|}
\hline Author, year & $\begin{array}{c}\text { Age } \\
\text { (year)/sex }\end{array}$ & $\begin{array}{l}\text { Cancer type } \\
\text { and stage }\end{array}$ & $\begin{array}{c}\text { Occurrence of renal } \\
\text { damage in relation to } \\
\text { cancer diagnosis }\end{array}$ & $\begin{array}{c}\text { Renal } \\
\text { presentation }\end{array}$ & Treatment & Outcome \\
\hline Meyrier et al. [5] 1985 & $59 / \mathrm{M}$ & NSCLC & One year ago & NS & Chemotherapy & Died \\
\hline Richmond et al. [6] 1990 & $72 / \mathrm{M}$ & $\begin{array}{l}\text { Bronchial } \\
\text { carcinoma }\end{array}$ & Simultaneously & Necropsic diagnosis & None & Died \\
\hline Garthwaite et al. [7] 2003 & $64 / \mathrm{M}$ & Bronchial SCC & Simultaneously & NS, RI & Palliative & Hemodialysis \\
\hline Paydas et al. [8] 2005 & $50 / \mathrm{M}$ & NSCLC IIIB & 2 years ago & NS, CRF & Patient refusal & Hemodialysis \\
\hline Nobata et al. [2] 2012 & $71 / \mathrm{M}$ & $\begin{array}{l}\text { Metastatic lung } \\
\text { tumor from RCC }\end{array}$ & RCC 8 years ago & NS, ARF on CKD & Surgery & Hemodialysis \\
\hline Our case & $56 / \mathrm{M}$ & NSCLC IIIB & 1 year ago & NS, ARF & Palliative & $\begin{array}{l}\text { Renal function } \\
\text { worsening }\end{array}$ \\
\hline
\end{tabular}

M: male, SCC: squamous cell carcinoma, NS: nephrotic syndrome, RI: renal insufficiency, CRF: chronic renal failure, ARF: acute renal failure, NSCLC: non small cell lung cancer, and RCC: renal cell carcinoma.

cytokines (IL-1 $\beta$, IL-6, and TNF- $\alpha$ ) produced by antitumor lymphocytes or macrophages can induce SAA production and development of AA amyloidosis.

In conclusion, lung cancer could be included in the list of neoplastic diseases predisposing to AA amyloidosis.

\section{Disclosure}

The paper is not under simultaneous consideration by any other publication. All authors confirmed that they read the paper and agree to its publication in this form.

\section{Conflict of Interests}

All authors do not disclose any sponsorship or funding arrangements relating to their research and any conflict of interests.

\section{References}

[1] R. W. Simms, M. N. Prout, and A. S. Cohen, “The epidemiology of AL and AA amyloidosis," Baillieres Clinical Haematology, vol. 8, no. 3, pp. 627-634, 1994.

[2] H. Nobata, N. Suga, A. Itoh et al., "Systemic AA amyloidosis in a patient with lung metastasis from renal cell carcinoma," Amyloid, vol. 19, no. 4, pp. 197-200, 2012.

[3] K. G. Kimball, "Amyloidosis in association with neoplastic disease. Report of an unusual case and clinicopathological experience at memorial center for cancer and allied diseases during eleven years (1948-1958)," Annals of Internal Medicine, vol. 55, pp. 958-974, 1961.

[4] L. Berger and M. W. Sinkoff, "Systemic manifestations of hypernephroma: a review of 273 cases," The American Journal of Medicine, vol. 22, no. 5, pp. 791-796, 1957.

[5] A. Meyrier, R. Makdassi, J. L. Breau, J. Amouroux, and B. Mougenot, "AA amylosis and the nephrotic syndrome complicating a pulmonary epidermoid carcinoma," Nephrologie, vol. 6, no. 4, pp. 191-192, 1985.

[6] I. Richmond, P. S. Hasleton, and S. Samadian, "Systemic amyloid associated with carcinoma of the bronchus," Thorax, vol. 45 , no. 2 , pp. 156-157, 1990.
[7] E. A. Garthwaite, L. Sellars, and S. Bhandari, "Carcinoma of the bronchus presenting as renal failure secondary to amyloidosis," Nephrology Dialysis Transplantation, vol. 18, no. 5, pp. 1031-1032, 2003.

[8] S. Paydas, B. Soydas, S. Paydas, M. Balal, S. Erdogan, and I. Tuncer, "Different glomerulopathies accompanying non-smallcell lung cancer," Mount Sinai Journal of Medicine, vol. 72, no. 4, pp. 279-281, 2005.

[9] J. C. Lee, H. Yamauchi, and J. Hopper Jr., "The association of cancer and the nephrotic syndrome," Annals of Internal Medicine, vol. 64, no. 1, pp. 41-51, 1966.

[10] L. Jørgensen, I. Heuch, T. Jenssen, and B. K. Jacobsen, "Association of albuminuria and cancer incidence," Journal of the American Society of Nephrology, vol. 19, no. 5, pp. 992-998, 2008.

[11] B. Ebert, K. Shaffer, and H. Rennke, "Some unusual paraneoplastic syndromes: case 4. Paraneoplastic nephrotic syndrome in a patient with lung cancer," Journal of Clinical Oncology, vol. 21, no. 13, pp. 2624-2625, 2003.

[12] D. M. Burstein, S. M. Korbet, and M. M. Schwartz, "Membranous glomerulonephritis and malignancy," The American Journal of Kidney Diseases, vol. 22, no. 1, pp. 5-10, 1993.

[13] K. G. Kimball, "Amyloidosis in association with neoplastic disease," Annals of Internal Medicine, vol. 55, no. 6, pp. 958-974, 1961.

[14] M. Dictor and R. Hasserius, "Systemic amyloidosis and nonhematologic malignancy in a large autopsy series," Acta Pathologica et Microbiologica Scandinavica A, vol. 89, no. 6, pp. 411416, 1981.

[15] A. Ramankulov, M. Lein, M. Johannsen et al., "Serum amyloid A as indicator of distant metastases but not as early tumor marker in patients with renal cell carcinoma," Cancer Letters, vol. 269, no. 1, pp. 85-92, 2008. 


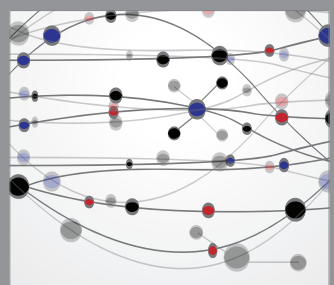

The Scientific World Journal
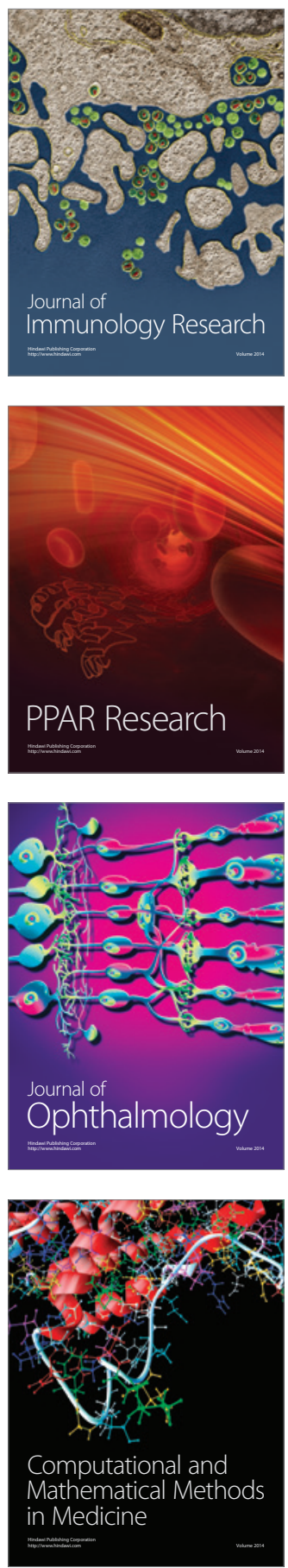

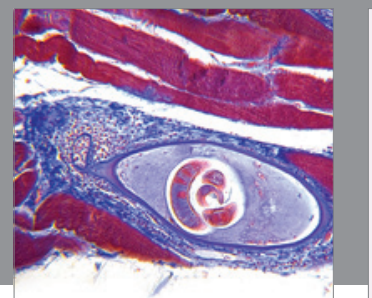

Gastroenterology

Research and Practice
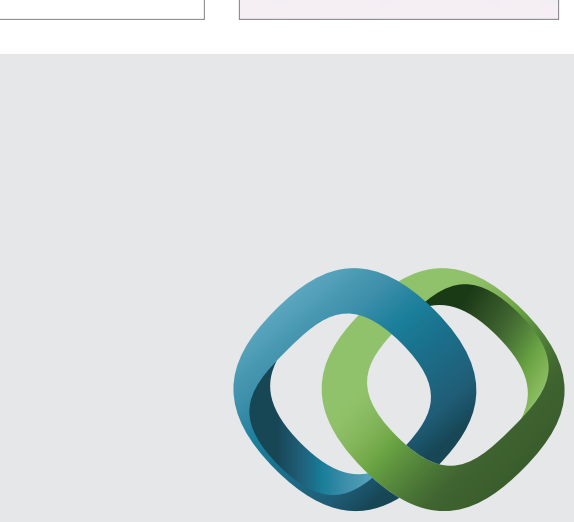

\section{Hindawi}

Submit your manuscripts at

http://www.hindawi.com
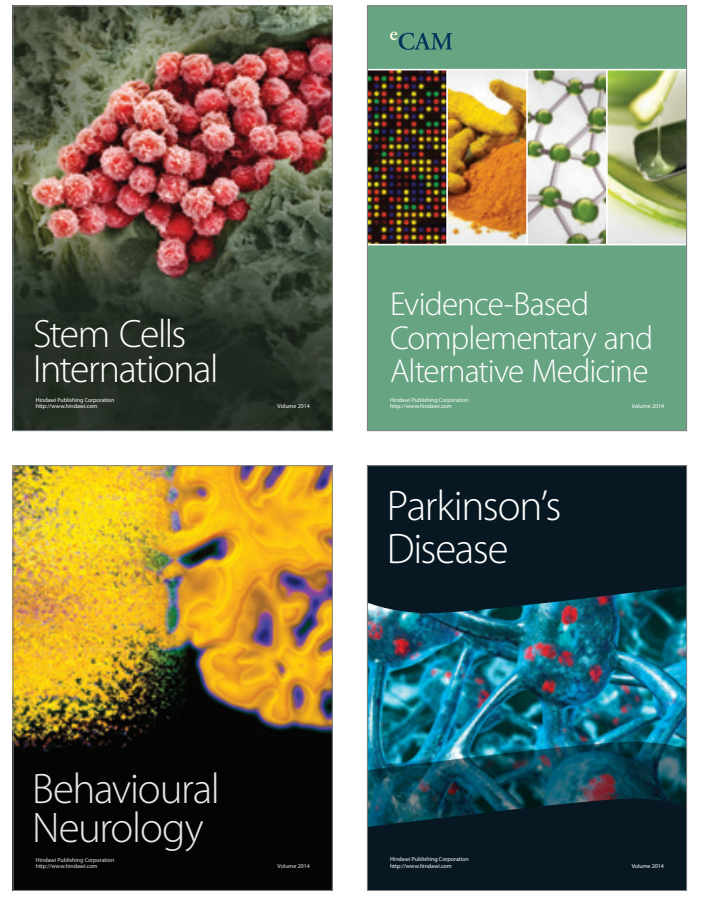
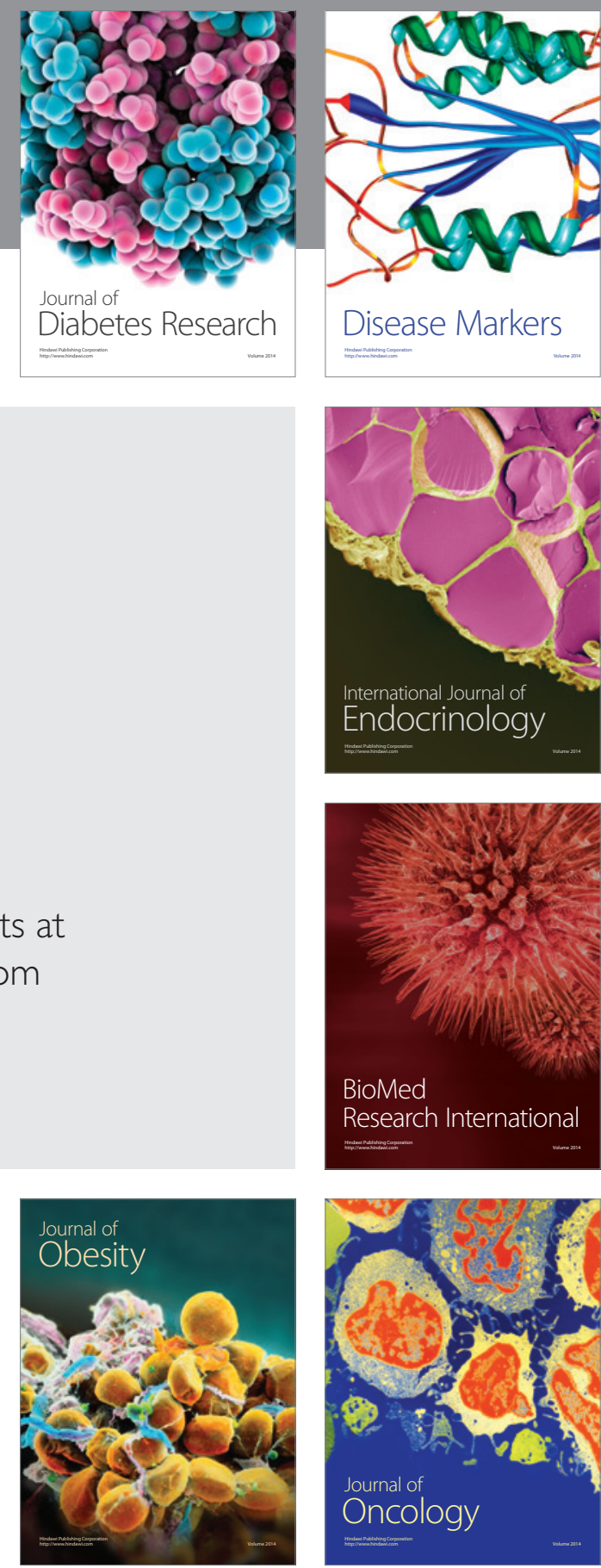

Disease Markers
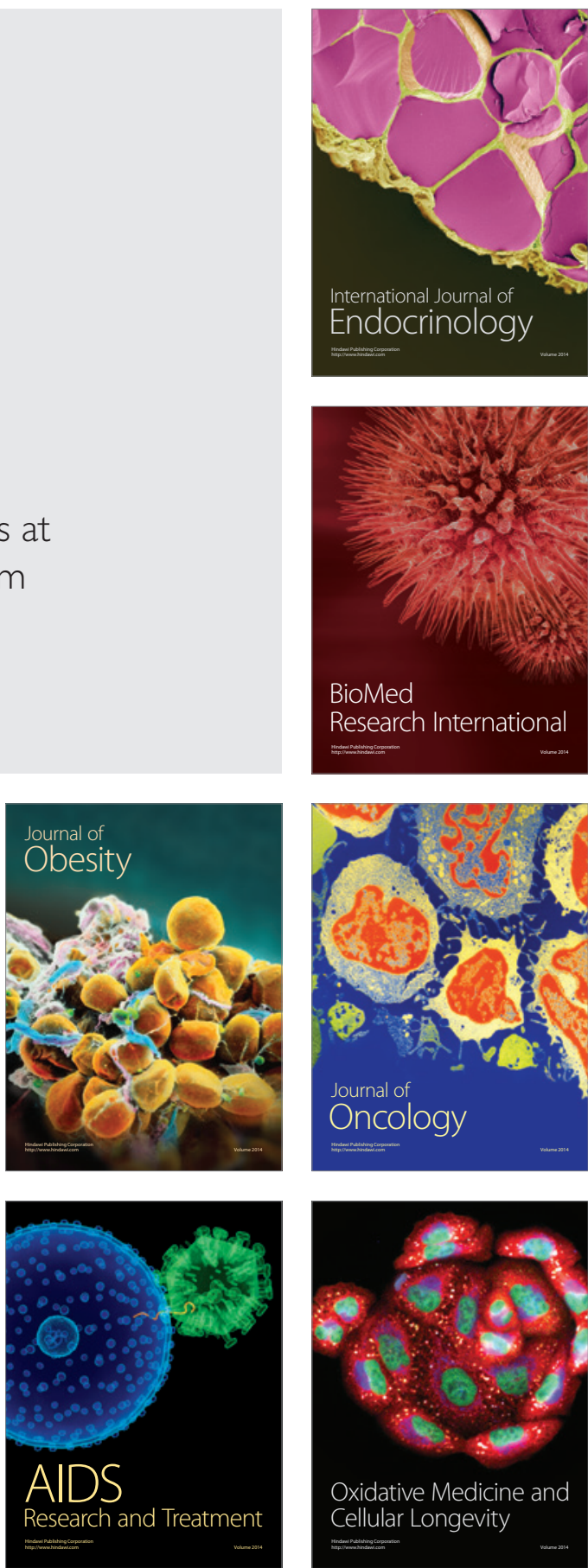